\title{
Б.А. АБДУРАХМАНОВ ${ }^{1}$, З.К. АВИЗОВА
}

${ }^{1}$ Южно-Казахстанская медицинская академия, Шымкент, Республика Казахстан

\section{Смертность от рака легкого из-за задержки лечения: Обзор литературы}

Актуальность: Рак легких продолжает занимать лидирующие позиции в структуре онкологической заболеваемости и смертности во всем мире. При задержке соответствующего лечения рака легкого существует высокая вероятность летального исхода.

Цель: изучение зарубежных научных публикаций последних лет о смертности от рака легкого из-за задержки лечения.

Результаты: Результаты анализа зарубежных исследований за 2010-2020 годы показывают, что любая задержка лечения после постановки диагноза рака легкого приводит к снижению выживаемости. Исследования последних лет позволяют количественно оценить влияние задержки лечения на смертность от рака для определения приоритетов и моделирования. По показаниям хирургического и системного лечения, а также лучевой терапии по семи видам рака, в том числе рака легкого, установлено наличие значимой связи между задержкой лечения и повышенной смертностью. Как считают исследователи, наиболее эффрективное лечение связано именно с ранней диагностикой.

Заключение: Анализ различных факторов, препятствующих своевременному лечению рака лёгких, послужит основой для уточнения и оптимальной оченки влияния отсрочки лечения на выживаемость. Политика, направленная на минимизацию задержек лечения, может улучшить результаты выживаемости.

Ключевые слова: рак легкого, немелкоклеточный рак легкого (НМРЛ), задержка лечения, выживаемость.

\section{Введение}

Неинфекционные заболевания, в том числе рак легкого, в настоящее время являются причиной большинства смертей во всем мире [1]. По данным GLOBOCAN, в 2020 году было зарегистрировано более 19,2 миллионов новых случаев заболевания злокачественными новообразованиями и более 9,9 миллионов смертей от них. Среди них рак легкого занимает второе место по заболеваемости $(11,4 \%$ от общего числа случаев рака) и первое место в структуре смертности (18,0\% от общего числа смертей от рака) [2].

Промедление с лечением рака может иметь неблагоприятные последствия для пациента. Однако, несмотря на фундаментальную важность лечения рака, отсутствуют стандартизированные оценки влияния отсрочки лечения на выживаемость для большинства показаний к лечению. Приведенные в статье метаанализы содержат доказательства наличия регулярной связи между задержкой лечения и смертностью [3]. Изучение влияния задержки на смертность и другие исходы, такие как рецидив или финансовые аспекты, имеет большое значение для разработки систем лечения рака, путей и моделей оказания помощи, обеспечивающих доступные и эффективные результаты [4].

Отметим, что необходимость в глубоком понимании влияния отсрочки лечения на исходы резко возросла во время пандемии коронавируса COVID-19. В этот период во многих странах произошла отсрочка плановой хирургии рака и лучевой терапии, а также сокращение применения системного лечения [5, 6], поскольку в системе ресурсы здравоохранения были перераспределены с целью обеспечения готовности к пандемии [7].

\section{Материалы и методы:}

В данный обзор были включены результаты зарубежных исследований по изучению проблемы смертности от рака легкого из-за задержки лечения за 2010-2020 годы. Нами были использованы англоязычные публикации, включенные в электронную поисковую систему PubMed, Science Direct, Google Scholar и поисковые системы библиотечных баз данных Всемирной организации здравоохранения (ВО3), с использованием таких ключевых слов, как рак легкого, немелкоклеточный рак легкого (НМРЛ), задержка лечения, выживаемость.

\section{Результаты и Обсуждение:}

По мнению большинства исследователей, доступ к комплексным качественным медицинским услугам является важным фактором в укреплении здоровья, профилактике и лечении заболеваний. В публикациях последовательно подчеркивается необходимость своевременного использования медицинских услуг для достижения наилучших результатов [8-12].

Исследования показывают, что рост бремени рака характерен для стран с низким уровнем доходов, где неэффективное лечение рака легкого приводит к негативным результатам для здоровья [13-16]. Однако во многих случаях расхождения в результатах зависят от различия в качестве медицинской помощи, включая время постановки диагноза, тип используемых диагностических методов, стадию заболевания, начало и тип лечения [15, 17-18]. Признание, анализ и сообщение этих препятствий создают основу для улучшения качества, а также разработки и оценки эффективных корректирующих вмешательств в существующие процессы лечения рака легких [19].

В частности, в исследовании американских ученых показано, что для выживания пациентов с ранней стадией НМРЛ очень важно своевременное хирургическое вмешательство. По наблюдениям исследователей, пациент в возрасте 60 лет с диагнозом НМРЛ стадии IIB >4 см, получивший лечение в течение 2 недель, имеет 50\%ный шанс выживания в течение 5 лет. Если этого пациента лечить через 4 недели после постановки диагноза, то

Б.А. Абдурахманов \В.A. Abdurakhmanov - (1) 0000-0003-3448-4448,

Z.K. Avizova \3.K. Авизова - (1) 0000-0001-5540-0229, e-mail: zeinepavizova@mail.ru 
вероятность 5-летней выживаемости снижается до 47\%. Это эквивалентно тому, чтобы прожить еще 0,4 года. Для 30-летнего пациента, 5-летняя выживаемость составляет 71\% при лечении в течение 2 недель [20]. Ученые считают, что поставщики первичной медицинской помощи и специалисты обязаны обеспечивать пациентов с ранними стадиями рака легкого наиболее эффективным в этом случае хирургическим лечением [21].

Согласно Samson et al., задержка хирургического вмешательства у пациентов с ранней стадией НМРЛ является распространенным явлением и часто бывает связана с социально-экономическими и клиническими факторами. Значительные задержки в оказании медицинской помощи, по мнению авторов, привели к неблагоприятным краткосрочным и долгосрочным исходам для пациентов [22].

Anggondowati et al., проанализировавшие данные Национальной базы данных по раку США у взрослых пациентов с впервые установленным диагнозом НМРЛ, пришли к выводу, что более длительное время лечения не способствует лучшей выживаемости. Однако задержка лечения не оказывает пагубного воздействия на пациентов с более поздними стадиями заболевания. По сравнению с лечением, начатым от 1 дня до 4 недель после установления диагноза, сроки лечения в 4-6 недель приводили к снижению риска смерти для пациентов с ранней стадией рака, местно-распространенного рака или метастатического рака. Точно также, более низкий риск смерти был связан с длительностью лечения более 6 недель для пациентов с любой стадией рака на момент постановки диагноза.

Анализ пациентов, получивших хирургическое вмешательство на ранних стадиях заболевания, показал, что длительное время до операции было связано с более высоким риском смерти. Комплексные обследования и подготовка приносят пациентам большую пользу, но не ускоряют лечение. Однако для пациентов с операбельными видами рака важно не затягивать лечение. По мнению авторов, будущие исследования должны быть сосредоточены на выявлении у пациентов клинических характеристик, которые могли бы предсказать оптимальное время для достижения лучших результатов, что было бы полезно для пациентов и послужило бы основой для улучшения клинических стандартов. Такие исследования, как считают ученые, были бы актуальны с учётом разночтений в руководящих принципах в отношении сроков начала лечения НМРЛ [23].

Это исследование подтверждает идею о том, что выделение времени для оптимального планирования лечения, хотя и приводит к более длительному интервалу до начала лечения, вероятно, увеличивает выживаемость пациентов. Представляется разумным начинать лечение пациентов с резектабельным ранним раком легкого в течение 4 недель после постановки диагноза. Это связано с ожидаемым увеличением числа пациентов на ранних стадиях заболевания после улучшения скрининговых программ и недавних рекомендаций, выданных Американской рабочей группой по профилактическим мероприятиям (U.S. Preventive Services Task Force). Несмотря на различные факторы, приводящие к задержкам лечения, следует предпринять попытки уменьшить задержки, вызванные системными факторами [23].

По результатам мета-анализа, проведенного рядом исследователей, существует установленная связь между задержкой лечения и смертностью. Было проанализировано семь видов рака, которые вместе составляют
44\% всех случаев рака в мире [3]. Это 5 распространенных видов рака (мочевого пузыря, груди, толстой кишки, прямой кишки, легких), а также рак шейки матки (учтено его глобальное значение как четвертый по частоте диагноз рака среди женщин) и рак головы и шеи (основное бремя в странах со средним уровнем дохода). Исследования были ограничены англоязычными публикациями с 2010 по 2020 годы, в которых сообщалось конкретно о задержке лечения и выживаемости. Авторы обнаружили, что по всем трем методам лечения (хирургическое вмешательство, системные лечение и лучевая терапия) отсрочка лечения на четыре недели связана с увеличением риска летального исхода. Для операции, это увеличение риска смерти на 6-8\% на каждые четыре недели задержки [24-30].

\section{Выводы:}

Таким образом, проанализированные исследования показывают, что задержка лечения рака легкого после постановки диагноза снижает выживаемость больных. Требуется дальнейшее изучение факторов, препятствующих своевременному началу лечения, и поиск путей преодоления этих препятствий.

\section{Список использованных источников}

1. World Health Organization. Global Health Estimates: Life expectancy and leading causes of death and disability // www.who. int/data/gho/data/themes/mortality-and-global-health-estimates. 03.06.2021;

2. International Agency for Research on Cancer. The Global Cancer Observatory Globocan 2020. All cancers // gco.iarc.fr/today/ data/factsheets/cancers/39-All-cancers-fact-sheet.pdf. 03.06.2021;

3. Hanna T.P. et al. Mortality due to cancer treatment delay: systematic review and meta-analysis // BMJ. - 2020. - № 371. - m4087. doi: 10.1136/bmj.m4087

4. Institute of Medicine (US) Committee on Quality of Health Care in America. Crossing the Quality Chasm: A New Health System for the 21st Century. - National Academies Press (US), 2001. doi: 10.17226/10027;

5. Sample I. More than $2 m$ operations cancelled as NHS fights COVID-19// Guardian. - 26 Apr 2020. ;

6. Harnett C.E. Clearing surgery backlog will take at least 17 months and cost millions, province says //Times Colonist. - 7 May 2020.;

7. Hanna T.P., Evans G.A., Booth C.M. Cancer, COVID-19 and the precautionary principle: prioritizing treatment during a global pandemic // Nat. Rev. Clin. Oncol. - 2020. - № 17(5). - C. 268-270. doi: 10.1038/s41571-020-0362-6;

8. Shankar A. et al. Feasibility of lung cancer screening in developing countries: challenges, opportunities and way forward // Transl. Lung Cancer Res. - 2019. - № 8(Suppl. 1). - C. S106-S121. doi: 10.21037/t/cr.2019.03.03;

9. Sullivan T., Sullivan R., Ginsburg O. M. Screening for cancer: considerations for low-and middle-income countries // B KH.: Cancer: Disease Control Priorities / nod ped. Gelband H., Jha P., Sankaranarayanan $R$. u дp. - Изд. 3. - Washington (DC): The International Bank for Reconstruction and Development / The World Bank, 2015. - Tом 3. doi: 10.1596/978-1-4648-0349-9_ch12;

10. Sankaranarayanan R. Screening for cancer in low-and middle-income countries // Annals Global Health. - 2014. - №80(5). - C. 412-417. doi: 10.1016/j.aogh.2014.09.014;

11. Ambroggi M. et al. Distance as a barrier to cancer diagnosis and treatment: review of the literature // Oncologist. - 2015. №20(12). - C. 1378-1385. doi: 10.1634/theoncologist.2015-0110;

12. Mills A. Health policy and systems research: defining the terrain; identifying the methods // Health Policy Planning. - 2012. - № 27(1). - C. 1-7. doi: 10.1093/heapol/czro06;

13. Bray F. et al. Global cancer statistics 2018: GLOBOCAN estimates of incidence and mortality worldwide for 36 cancers in 185 countries // CA: Cancer J. Clin. - 2018. - №68(6). - C. 394-424. doi: 10.3322/caac.21492; 
14. Pakzad R., Mohammadian-Hafshejani A, Ghoncheh M, Pakzad I, Salehiniya $H$. The incidence and mortality of lung cancer and their relationship to development in Asia // Transl. Lung Cancer Res. - 2015. - №4(6). - C. 763-774. doi: 10.3978/j.issn.22186751.2015.12.01;

15. Walton L. et al. Patient perceptions of barriers to the early diagnosis of lung cancer and advice for health service improvement // Family Practice. - 2013. - № 30(4). - C. 436-444. doi:10.1093/fampra/cmt001;

16. Denny L., Anorlu R. Cervical cancer in Africa // Cancer Epidemiol. Biomarkers. Prev. - 2012. - №21(9). - C. 1434-1438. doi:10.1158/1055-9965.EPI-12-0334;

17. Urman A. et al. Burden of lung cancer and associated risk factors in Africa by region // J. Pulm. Respir. Med. - 2016. - №6(3). 1000340. doi: 10.4172/2161-105X.1000340;

18. Winkler V., Mangolo N. J., Becher H. Lung cancer in South Africa: a forecast to 2025 based on smoking prevalence data // BMJ open. - 2015. - №5(3). - e006993. doi: 10.1136/bmjopen-2014-006993;

19. Carrillo J. E. et al. Defining and targeting health care access barriers // J Health Care Poor Underserved. - 2011. - №22(2). - C. 562-575. doi: 10.1353/hpu.2011.0037;

20. Kanarek N. F. et al. Survival after community diagnosis of early-stage non-small cell lung cancer // Am. J. Med. - 2014. - №127(5). - C. 443-449. doi: 10.1016/j.amjmed.2013.12.023;

21. Dovidio J. F., Fiske S. T. Under the radar: how unexamined biases in decision-making processes in clinical interactions can contribute to health care disparities //Am. J. Public Health. - 2012. №102(5). - C. 945-952. doi: 10.2105/AJPH.2011.300601;

22. Samson P., Patel A., Garrett T., Crabtree T., Kreisel D., Krupnick A.S., Patterson G.A., Broderick S., Meyers B.F., Puri V. Effects of Delayed Surgical Resection on Short-Term and Long-Term Out- comes in Clinical Stage I Non-Small Cell Lung Cancer // Ann Thorac Surg. - 2015. - №99(6). - C. 1906-1913. doi:10.1016/j.athoracsur.2015.02.022;

23. Anggondowati T., Ganti A. K., Islam K.M.M. Impact of time-totreatment on overall survival of non-small cell lung cancer patients an analysis of the national cancer database//Transl. Lung Cancer Res. - 2020. - №9(4). - C. 1202-1211. doi: 10.21037/t/cr-19-675;

24. Ferlay J. et al. Estimating the global cancer incidence and mortality in 2018: GLOBOCAN sources and methods //Int. J. Cancer. - 2019. - №144(8). - C. 1941-1953. doi: 10.1002/ijc.31937;

25. Chen Z. et al. The relationship between waiting time for radiotherapy and clinical outcomes: a systematic review of the literature // Radiother. Oncology. - 2008. - №87(1). - C. 3-16. doi: 10.1016/j.radonc.2007.11.016;

26. Jhawar S. et al. Adjuvant chemoradiation therapy for cervical cancer and effect of timing and duration on treatment outcome // Int. J. Radiat. Oncol. Biol. Phys. - 2017. - №98(5). - C. 1132-1141. doi: 10.1016/j.ijrobp.2017.03.045;

27. Booth C.M. et al. Time to adjuvant chemotherapy and survival in non-small cell lung cancer: A population-based study // Cancer. - 2013. - №119(6). - C. 1243-1250. doi: 10.1002/cncr.27823;

28. Salazar M.C. et al. Association of delayed adjuvant chemotherapy with survival after lung cancer surgery // JAMA oncol. 2017. - №3(5). - C. 610-619. doi: 10.1001/jamaoncol.2016.5829;

29. Tsai C.H. et al. Effect of time interval from diagnosis to treatment for non-small cell lung cancer on survival: a national cohort study in Taiwan // BMJ open. - 2020. - №10(4). - e034351. doi: 10.1136/bmjopen-2019-034351;

30. McMillan M. et al. Radiation treatment time and overall survival in locally advanced non-small cell lung cancer // Int. J. Radiat. Oncol. Biol. Phys. - 2017. - №98(5). - C. 1142-1152. doi: 10.1016/j. ijrobp.2017.04.004.

\section{ТҰЖЫРЫМ}

\section{Б.А. Абдурахманов ${ }^{1}$, 3.К. Авизова}

${ }^{1}$ Оңтүстік Қазақстан медицина академиясы, Шымкент, Қазақстан Республикасы

\section{Емдеудің кешігуіне байланысты өкпе қатерлі ісігінен болатын өлім: Әдебиетке шолу}

Өзектілігі: өкпенің қатерлі ісігі бүкіл әлемде онкологиялық аурулар мен өлім-жітім құрылымында жетекші орын алады. Өкпенің қатерлі ісігін тиісті емдеуді кешіктірген кезде өлім ықтималдығы болу мүміндігі жоғары.

Мақсаты: емдеудің кешігуіне байланысты өкпе қатерлі ісігінен болатын өлім туралы соңғы жылдардағы шетелдік ғылыми жарияланымдарды зерттеу.

Нәтижелер: 2010-2020 жылдардағы шетелдік зерттеулерді талдау нәтижелері өкпе қатерлі ісігі диагнозынан кейін емдеудің кез-келген кідірісі өмір сүрудің төмендеуіне әкелетінін көрсетеді. Соңғы жылдардағы зерттеулер басымдықты анықтау және модельдеу үшін емдеуді кешіктірудің қатерлі ісік ауруынан болатын өлімге әсері тигізетінін анықтауға мүмкіндік береді. Хирургиялық және жүйелі емдеу, сондайақ обырдың жеті түрі, оның ішінде өкпе қатерлі ісігі бойынша сәулелік терапия көрсетілімдері бойынша емдеудің кешігуі мен өлім-жітімнің жоғарылауы арасында елеулі байланыстың болуы анықталды. Зерттеушілердің пікірінше, ең тиімді емдеу ерте диагнозбен байланысты.

Қорытынды: өкпенің қатерлі ісігін уақтылы емдеуге кедергі келтіретін әртүрлі факторларды талдау кешіктірілген емнің өмір сүру деңгейіне әсерін анықтауға және оңтайлы бағалауға негіз болады. Емдеудің кідірістерін азайтуға бағытталған саясат өмір сүру нәтижелерін жақсарта алады.

Түйінді сөздер: өкпе қатерлі ісігі, кіші жасушалық емес өкпе қатерлі ісігі (NMRL), емдеуді кешіктіру, өмір сүру.

\section{ABSTRACT}

\section{B.A. Abdurakhmanov ${ }^{1}$, Z.K. Avizova}

${ }^{1}$ South-Kazakhstan Medical Academy, Shymkent, the Republic of Kazakhstan

\section{Lung cancer mortality due to delayed treatment: Literature review}

Relevance: Lung cancer is still leading in the structure of cancer incidence and mortality worldwide. Delay in appropriate treatment increases the probability of death from this disease.

Purpose: to study foreign scientific publications of recent years on the mortality from lung cancer due to delayed treatment.

Results: The analysis of global literature for 20102020 shows that any delay in lung cancer treatment after establishing the diagnoses reduces the survival rates. Recent studies provide a qualitative assessment of the effect of delay in treatment on cancer mortality for prioritization and modeling. The indications for surgery, systemic treatment, and radiation therapy in seven types of cancer, including lung cancer, evidence a significant association between delay in treatment and increased mortality. The researchers believe that early diagnostics increase the treatment efficacy.

Conclusion: Analyzing the barriers to timely treatment for lung cancer can help clarify and assess the impact of delayed treatment on survival. Policies designed to minimize delays in treatment can improve survival outcomes.

Keywords: lung cancer, non-small cell lung cancer (NS$(L C)$, delayed treatment, survival. 